\title{
The Current Practice of Hypertensive Crises Treatment and the Underestimated Role of Clinical Pharmacists in Ambo Hospital Medical Ward, Ethiopia
}

Minyahil A Woldu ${ }^{1 * \#}$, Jimma L Lenjisa"\#, Gobezie T Tegegne ${ }^{2}$, Derartu G Yadeta ${ }^{2}$ and Deressa T Chala ${ }^{2}$

${ }^{1}$ Department of Pharmacology and Clinical Pharmacy, School of pharmacy, College of Health Sciences, Addis Ababa University, Addis Ababa, Ethiopia ${ }^{2}$ Ambo University, College of Medicine and Health Sciences, Department of Pharmacy, Clinical Pharmacy Unit; Ambo, Ethiopia

\#These authors have contributed equally to the paper

\begin{abstract}
Background: Hypertension is an extremely common clinical problem, affecting approximately 1 billion individuals worldwide. An estimated $1 \%$ to $2 \%$ of patients with chronic hypertension will at some time develop hypertensive crises (Hypertensive urgency and emergency). Hypertensive urgency and emergency are differentiated by the absence or presence of acute end-organ damage, respectively. The blood pressure of patients with hypertensive emergencies should be reduced rapidly during the treatment. It should not be reduced to the normal value, but by approximately $20-30 \%$ of the baseline value. The reason for a stepwise reduction in blood pressure is the fact that patients with chronic hypertension have an altered auto regulation curve.
\end{abstract}

Case presentation: A 60 year old male patient, who has been a known hypertensive patient admitted due to sudden onset of body weakness, difficulty of speech, diverted lips towards the left side, difficulties in eating, moving, coughing and inability to move right side of his extremities since one day. On P/E the pt. was severely sick looking, and unconscious.

Conclusion: A number of both parenteral and oral antihypertensive drugs can be used in these patients. Treatment of hypertensive crises in patients with hypertensive encephalopathy, intracranial haemorrhage, subarachnoid haemorrhage, and thrombotic stroke has been recommended to be initiated with nicardipine, fenoldopam, nimodipine, flunarizine or labetalol.

Keywords: Malignant hypertension; Hypertensive crises; Accelerated hypertension; Hypertensive urgency; Hypertensive emergency

Acronyms and Abbreviations: BP: Blood Pressure; C/C: Chief Complaints; FH: Family History; Hx: History; JNC VII: The Seventh Report of the Joint National Committee on Prevention, Detection, Evaluation and Treatment of High Blood Pressure; P/E: Physical Examination; PMH: Past Medical History; SH: Social History

\section{Introduction}

Hypertension is an extremely common clinical problem, affecting approximately 1 billion individuals worldwide [1]. The incidence and prevalence of hypertensive crises have been little addressed in the literature. However, over the last decade increasing numbers of young patients with different forms of the disease have been observed in emergency departments [2]. An estimated $1 \%$ to $2 \%$ of patients with chronic hypertension will at some time develop hypertensive crises. According to recent data from the National Health and Nutrition Examination Survey (NHANES) 1999 to 2010, the prevalence of hypertension has remained stable at $30.5 \%$ among men and $28.5 \%$ among women in the United States; however, $74 \%$ of the hypertensive population is unaware of having this condition [3]. Furthermore, the prevalence of hypertension increases with age, affecting $75 \%$ of people over the age of 70 [4].

According, to the Seventh Report of the Joint National Committee on Prevention, Detection, Evaluation and Treatment of High Blood Pressure (JNC-VII Report) and American Heart Association blood pressure in adults has generally been classified as normal (90-119/60-79 $\mathrm{mmHg}$ ), pre-hypertension (120-139 $\mathrm{mmHg} / 80-89 \mathrm{mmHg}$ ), stage one hypertension (140-159 $\mathrm{mmHg} / 90-99 \mathrm{mmHg}$ ), stage two hypertension $(160-179 / 100-109 \mathrm{mmHg})$ and hypertension crisis $(\geq 180 / 110 \mathrm{mmHg})$ [5-7].

The terms malignant hypertension, hypertensive crises, and accelerated hypertension have been replaced by hypertensive urgency or Hypertensive Emergency. Hypertensive urgency and emergency are differentiated by the absence or presence of acute end-organ damage, respectively $[3,8]$ and its classification and management have been recently reviewed in the context of both European and American guidelines. The key points for proper blood pressure control in severe arterial hypertension are: Distinction between urgent intervention and emergencies, Choice of the best drug(s), and Choice of the correct route of administration [9]. The most important causes of hypertensive crises are non-compliance (reduction or interruption of therapy), inadequate therapy, endocrine disease, renal (vessel) disease, pregnancy and intoxication (drugs) [10]. Severe hypertension is often seen in the setting of acute strokes. The elevation in BP could be from the stress of the stroke, a physiologic response to hypoxia, or the result of the body's attempt to increase and maintain cerebral perfusion in the setting of an ischemic stroke. Alternatively, severe hypertension may have caused the acute stroke [11]. Overall a wide range of therapeutic options are available however its management in hospitals of developing countries is haltered by a number of factors. Therefore, the aim of this case presentation is to review the current knowledge and treatment trends in Ambo hospital,

*Corresponding author: Minyahil A Woldu, Department of Pharmacology and Clinical Pharmacy, School of Pharmacy, College of Health Sciences, Addis Ababa University, Addis Ababa-Ethiopia, Tel: +251912648527 ; E-mail: minwoldu@gmail.com

Received August 22, 2014; Accepted October 22, 2014; Published October 24 2014

Citation: Woldu MA, Lenjisa JL, Tegegne GT, Yadeta DG, Chala DT (2014) The Current Practice of Hypertensive Crises Treatment and the Underestimated Role of Clinical Pharmacists in Ambo Hospital Medical Ward, Ethiopia. J Clin Case Rep 4: 445. doi:10.4172/2165-7920.1000445

Copyright: (c) 2014 Woldu MA, et al. This is an open-access article distributed under the terms of the Creative Commons Attribution License, which permits unrestricted use, distribution, and reproduction in any medium, provided the original author and source are credited. 
Citation: Woldu MA, Lenjisa JL, Tegegne GT, Yadeta DG, Chala DT (2014) The Current Practice of Hypertensive Crises Treatment and the Underestimated Role of Clinical Pharmacists in Ambo Hospital Medical Ward, Ethiopia. J Clin Case Rep 4: 445. doi:10.4172/21657920.1000445

Page 2 of 5

Ethiopia; and to compare its trend with the standardize diagnosis and treatment approaches.

\section{Case Presentation}

\section{Case summary}

Patient's Name: I.S, Age: 60 year, Sex: M, Address: Ambo, Ethiopia, Date of admission: $17 / 03 / 14$

\section{$\mathrm{C} / \mathrm{C}$}

Sudden onset of body weakness, Difficulty of speech, Inability to move right side of his extremities since one day, His lips were diverted towards the left side, had difficulties in eating, moving and coughing.

\section{FH}

Divorced, father of five children ( 2 males and 3 females, all are married). He was imprisoned before 5 years, currently lives alone.

\section{PMH}

He has been known hypertensive patient.

SH

He's a history of using alcohol in daily base (2-4 pint beer at least $3 \mathrm{X}$ a week), uses salty diet and drinks coffee regularly (1 cup/day), smokes cigarettes (10-20 cigarettes/day).

\section{Investigations}

\section{$\mathbf{P} / \mathbf{E}$}

General appearance: severely sick looking, unconscious. HEENT: Pupil Dilated, Facial Palsy. Chest: Clear Sound, S1 and S2 Well Heard. Abdomen: Not Moving with Respiration. GUS: NAD. EXT: Loss of Pain on the Right Side of the Extremities (Tables 1-3).

\begin{tabular}{|c|c|c|c|c|}
\hline Date & BP $\mathbf{~ m m H g}($ time $)$ & PR beat/min & RR breath/min. & Tem. $\mathbf{c}^{\circ}$ \\
\hline $\mathbf{1 7 / 0 3 / 1 4}$ & $190 / 110(6 \mathrm{pm})$ & 98 & 32 & 38 \\
\hline $\mathbf{1 8 / 0 3 / 1 4}$ & $190 / 100(6 \mathrm{am})$ & 100 & 32 & 38 \\
\hline $\mathbf{1 9 / 0 3 / 1 4}$ & $220 / 110(10 \mathrm{pm})$ & 104 & 30 & 37.5 \\
\hline $\mathbf{2 0 / 0 3 / 1 4}$ & $170 / 100(6 \mathrm{am})$ & 100 & 30 & 38 \\
\hline $\mathbf{2 1 / 0 3 / 1 4}$ & $160 / 90(6 \mathrm{am})$ & 98 & 32 & 38.6 \\
\hline $\mathbf{2 2 / 0 3 / 1 4}$ & $140 / 90(6 \mathrm{am})$ & 90 & 30 & 37.8 \\
\hline
\end{tabular}

Table 1: Vital sign chart of I.S. Ambo hospital medical ward, Ambo, Ethiopia 2014

\begin{tabular}{|c|c|c|c|}
\hline \multirow{4}{*}{$\begin{array}{c}\text { CBC (peripheral } \\
\text { blood) }\end{array}$} & WBC & $3.5 \times 10^{3} / \mathrm{mm}^{3}$ & $3.54-9.06 \times 10^{3} / \mathrm{mm}^{3}$ \\
\cline { 2 - 4 } & Hgb & $15.09 \mathrm{gm} / \mathrm{dl}$ & $12.1-15.1 \mathrm{~g} / \mathrm{dL}($ female) \\
\cline { 2 - 4 } & Neut & $44.2 \%$ & $36.1-44.3 \%$ (female) \\
\cline { 2 - 4 } & lymph & $11.2 \%$ & $1.2-3.3 \times 10^{3} / \mu \mathrm{L}(25-35 \%)$ \\
\cline { 2 - 4 } & platelet & $170 \times 10^{3}$ & $140-415 \mathrm{cells} / \mathrm{mm}^{3}$ \\
\hline \multirow{2}{*}{ U/A } & WBC & Many & $3-4$ per low-power field \\
\cline { 2 - 4 } & RBC & Many & $1-2$ per low-power field \\
\cline { 2 - 4 } & Bacteria & Many & negative \\
\hline \multirow{2}{*}{ B/F } & o/p & no o/p seen & negative \\
\hline
\end{tabular}

Table 2: Laboratory chart of I.S. Ambo hospital medical ward, Ambo, Ethiopia.

\begin{tabular}{|c|c|c|}
\hline Date & Working Diagnosis & R/O \\
\hline $17 / 03 / 14$ & $\begin{array}{c}\text { Hemorrhagic Stroke }+ \\
\text { Hypertension Emergency }\end{array}$ & $\begin{array}{c}\text { Ischemic stroke and Head } \\
\text { injury }\end{array}$ \\
\hline $\mathbf{1 8 / 0 3 / 1 4}$ & Same as date 17/03/14 & \\
\hline
\end{tabular}

Table 3: Working diagnosis of I.S. Ambo hospital medical ward, Ambo, Ethiopia 2014.

\section{Differential Diagnosis}

Metabolic toxicity, Head injury, epilepsy, Anxiety disorders, cardiomyopathy, Cocaine toxicity, hypertrofic cardiomyopathy, Congestive Heart Failure and Pulmonary Edema, Hyperaldosteronism, Primary Hyperthyroidism, Thyroid Storm, and Graves' Disease, and Myocardial Infarction, all of which were ruled out. Exclusion was done based on physical examination, clinical pictures and laboratory diagnosis.

\section{Treatment}

\section{Non pharmacologic treatment}

Counselling and health education was provided to patient family on the use of the medication, the adherence problem the patient have and on how to live a better healthier life by the ward assigned clinical pharmacists. The points of the discussions include: The definition of what modified life style mean, why to restrict Salt and fat in the diet, the need of avoiding alcohols, smoking and cigarettes, etc.

$\checkmark$ Patient was admitted \& maintenance fluid secured

$\checkmark$ Position change was ordered to be done every 2 hours.

$\checkmark$ Patient was catheterized and physiotherapy was ordered.

$\checkmark \quad$ Monitoring Vital signs especially the BP, Q 6 hours.

$\checkmark \quad$ NG tube feeding.

\section{Pharmacologic treatment}

Clinical questions

- Was the patient treatment approaches according to the current major guidelines and standard books?

- What was the major drug therapy problems (DTPs) identified?

- Was the role of clinical pharmacists' significantly affected in management approaches?

- What was the role of the role of endothelial function and of carotid artery abnormalities in the overall cerebral lesions in hypertensive patients?

\section{Discussion}

\section{Current management approaches of hypertensive emergencies}

The blood pressure of patients with hypertensive emergencies should be reduced rapidly during the treatment. It should not be reduced to the normal value, but by approximately $20-30 \%$ of the baseline value. The reason for a stepwise reduction in blood pressure is the fact that patients with chronic hypertension have an altered auto regulation curve. Acute normotension would lead to hypo perfusion in these patients. Therefore, Immediate but careful reduction in blood pressure is indicated in hypertensive emergencies settings [10]. An excessive hypotensive response is potentially dangerous, possibly leading to ischemic complications such as stroke, myocardial infarction or blindness in some cases. Thus, in patients who are severely hypertensive but asymptomatic, slower reductions in blood pressure should be provided with oral agents [12]. Those without end-organ damage need to adjust or reinstate their regimens, but do not need immediate aggressive treatment [13].

A number of both parenteral and oral antihypertensive drugs can be used in these patients. For a rapid BP reduction parenteral 
Citation: Woldu MA, Lenjisa JL, Tegegne GT, Yadeta DG, Chala DT (2014) The Current Practice of Hypertensive Crises Treatment and the Underestimated Role of Clinical Pharmacists in Ambo Hospital Medical Ward, Ethiopia. J Clin Case Rep 4: 445. doi:10.4172/21657920.1000445

Page 3 of 5

\begin{tabular}{|c|c|c|}
\hline 1 & $17 / 03 / 14$ & $\begin{array}{ll}\checkmark & \text { Simvastatin } 20 \mathrm{mg} \text { po daily, } \\
\checkmark & \text { Catheterization and frequent bed position was ordered }\end{array}$ \\
\hline 2 & $18 / 03 / 14$ & $\begin{array}{ll}\checkmark & \text { HCT } 25 \mathrm{mg} \text { po daily, } \\
\checkmark & \text { Nifedipine } 20 \mathrm{mg} \text { po BID }\end{array}$ \\
\hline 3 & $19 / 03 / 14$ & $\begin{array}{l}\checkmark \text { Ceftriaxone } 1 \mathrm{~g} \text { iv BID for } 5 \text { days, } \\
\checkmark \text { NGT was secured }\end{array}$ \\
\hline 4 & $20 / 03 / 14$ & $\checkmark$ ASA $81 \mathrm{mg}$ po daily \\
\hline 5 & $21 / 03 / 14$ & $\checkmark \quad$ ASA was stopped \\
\hline 6 & $22 / 03 / 14$ & $\begin{array}{ll}\checkmark & \text { IV line secured with } 5 \% \text { DW, } \\
\checkmark & \text { Oxygen was administered, } \\
\checkmark & \text { Patient Expired at } 5 \mathrm{pm}\end{array}$ \\
\hline
\end{tabular}

Table 4: Medication and care plan history of I.S. Ambo hospital medical ward, Ambo, Ethiopia. 2014.

\begin{tabular}{|c|c|c|c|}
\hline Drug & Dose/Route & Onset of Action & Duration of Action \\
\hline $\begin{array}{l}\text { Nitroprusside } \\
50 \mathrm{mg} / 2 \mathrm{~mL} \text { (most commonly used) }\end{array}$ & $\begin{array}{l}\text { IV infusion } \\
\text { Start: } 0.5 \mathrm{mcg} / \mathrm{kg} / \mathrm{min} \\
\text { Usual: } 2-5 \mathrm{mcg} / \mathrm{kg} / \mathrm{min} \\
\text { Max: } 8 \mathrm{mcg} / \mathrm{kg} / \mathrm{min}\end{array}$ & Sec & $\begin{array}{l}\text { 3-5 min after D/C } \\
\text { infusion }\end{array}$ \\
\hline $\begin{array}{l}\text { Diazoxide } \\
300 \mathrm{mg} / 20 \mathrm{~mL}\end{array}$ & $50-150 \mathrm{mg} \mathrm{IV} \mathrm{Q} 5 \mathrm{~min}$ or as infusion of $7.5-30 \mathrm{mg} / \mathrm{min}^{d}$ & $1-5 \mathrm{~min}$ & $4-12 \mathrm{hr}$ \\
\hline $\begin{array}{l}\text { Enalaprilat } \\
1.25 \mathrm{mg} / \mathrm{mL} 2.5 \mathrm{mg} / 2 \mathrm{~mL}\end{array}$ & $0.625-1.25 \mathrm{mg}$ IV Q $6 \mathrm{hr}$ & $15 \min (\max , 1-4 \mathrm{hr})$ & $6-12 \mathrm{hr}$ \\
\hline $\begin{array}{l}\text { Esmolol } \\
100 \mathrm{mg} / 10 \mathrm{~mL} 2,500 \mathrm{mg} / 10 \mathrm{~mL} \text { concentrate }\end{array}$ & $250-500 \mathrm{mcg} / \mathrm{kg}$ over 1 minute then $50-300 \mathrm{mcg} / \mathrm{kg} / \mathrm{min}$ & $1-2 \min$ & $10-20 \mathrm{~min}$ \\
\hline $\begin{array}{l}\text { Fenoldopam } \\
10 \mathrm{mg} / \mathrm{mL} 20 \mathrm{mg} / 2 \mathrm{~mL} 50 \mathrm{mg} / 5 \mathrm{~mL}\end{array}$ & $0.1-0.3 \mathrm{mcg} / \mathrm{kg} / \mathrm{min}$ & $<5 \min$ & $30 \mathrm{~min}$ \\
\hline $\begin{array}{l}\text { Hydralazine } \\
20 \mathrm{mg} / \mathrm{mL}\end{array}$ & 10-20 mg IV & $5-20 \mathrm{~min}$ & $2-6 \mathrm{hr}$ \\
\hline $\begin{array}{l}\text { Labetalol } \\
20 \mathrm{mg} / 4 \mathrm{~mL} 40 \mathrm{mg} / 8 \mathrm{~mL} 100 \mathrm{mg} / 20 \mathrm{~mL} 200 \\
\mathrm{mg} / 20 \mathrm{~mL}\end{array}$ & $2 \mathrm{mg} / \mathrm{min} \mathrm{IV} \mathrm{or} 20-80 \mathrm{mg} \mathrm{Q} 10 \mathrm{~min}$ up to $300 \mathrm{mg}$ total dose & $2-5 \min$ & $3-6 \mathrm{hr}$ \\
\hline $\begin{array}{l}\text { Nicardipine } \\
25 \mathrm{mg} / 10 \mathrm{~mL}\end{array}$ & $\begin{array}{l}\text { IV loading dose } 5 \mathrm{mg} / \mathrm{hr} \text { increased by } 2.5 \mathrm{mg} / \mathrm{hr} \text { Q } 5 \text { min to desired } \\
\text { BP or a max of } 15 \mathrm{mg} / \mathrm{hr} \mathrm{Q} 15 \mathrm{~min} \text {, followed by maintenance } \\
\text { infusion of } 3 \mathrm{mg} / \mathrm{hr}\end{array}$ & $2-10 \min (\max , 8-12 \mathrm{hr})$ & $\begin{array}{l}40-60 \text { min after } D / C \\
\text { infusion }\end{array}$ \\
\hline $\begin{array}{l}\text { Nitroglycerin } \\
5 \mathrm{mg} / \mathrm{mL} 5 \mathrm{mg} / 10 \mathrm{~mL} 25 \mathrm{mg} / 5 \mathrm{~mL} 50 \mathrm{mg} / 10 \\
\mathrm{~mL} 100 \mathrm{mg} / 20 \mathrm{~mL}\end{array}$ & IV infusion pump $5-100 \mathrm{mcg} / \mathrm{min}$ & $2-5 \min$ & $\begin{array}{l}5-10 \min _{\text {infusion }} \text { after } \mathrm{D} C \mathrm{C} \\
\text { insion }\end{array}$ \\
\hline $\begin{array}{l}\text { Trimethaphan } \\
500 \mathrm{mg} / 10 \mathrm{~mL}\end{array}$ & IV infusion pump $0.5-5 \mathrm{mg} / \mathrm{min}$ & $1-5 \min$ & $\begin{array}{l}10 \text { min after } \mathrm{D} / \mathrm{C} \\
\text { infusion }\end{array}$ \\
\hline Phentolamine & 1-5 mg IV initially, repeat as needed & Immediate & $10-15 \min$ \\
\hline
\end{tabular}

Table 5: Parenteral Drugs Commonly Used in the Treatment of hypertensive emergencies [14].

\begin{tabular}{|c|c|c|}
\hline Major Side Effects (All Can Cause Hypotension) & Mechanism of Action & Avoid or Use Cautiously in Patients with These Conditions \\
\hline $\begin{array}{c}\text { Nausea, vomiting, diaphoresis, weakness, thiocyanate toxicity, cyanide } \\
\text { toxicity (rare) }\end{array}$ & $\begin{array}{l}\text { Arterial and venous } \\
\text { vasodilator }\end{array}$ & $\begin{array}{l}\text { Renal failure (thiocyanate accumulation), pregnancy, increased } \\
\text { intracranial pressure }\end{array}$ \\
\hline Hyperglycemia, Na retention, tachycardia, painful extravasation & Arterial vasodilator & $\begin{array}{l}\text { Angina pectoris, } \mathrm{Ml} \text {, aortic dissection, pulmonary edema, } \\
\text { intracranial hemorrhage }\end{array}$ \\
\hline Hyperkalemia & ACE inhibitor & $\begin{array}{l}\text { Hyperkalemia, renal failure in patients with dehydration or } \\
\text { bilateral renal artery stenosis, pregnancy (teratogenic) }\end{array}$ \\
\hline Nausea, thrombophlebitis, painful extravasation & $\beta$-adrenergic blocker & Asthma, bradycardia, decompensated HF, advanced heart block \\
\hline Tachycardia, headache, nausea, flushing & Dopamine-1 agonist & Glaucoma \\
\hline Tachycardia, headache, angina & Arterial vasodilator & Angina pectoris, Ml, aortic dissection \\
\hline Abdominal pain, nausea, vomiting, diarrhea & $\alpha$ - and $\beta$-adrenergic blocker & Asthma, bradycardia, decompensated HF \\
\hline $\begin{array}{l}\text { Headache, flushing, nausea, vomiting, dizziness, tachycardia; local } \\
\text { thrombophlebitis change infusion site after } 12 \mathrm{hr}\end{array}$ & $\begin{array}{l}\text { Arterial vasodilator ( } \mathrm{Ca} \\
\text { channel blocker) }\end{array}$ & Angina, decompensated HF, increased intracranial pressure \\
\hline $\begin{array}{l}\text { Methemoglobinemia, headache, tachycardia, nausea, vomiting, } \\
\text { flushing, tolerance with prolonged use }\end{array}$ & $\begin{array}{l}\text { Arterial and venous } \\
\text { vasodilator }\end{array}$ & $\begin{array}{l}\text { Pericardial tamponade, constrictive pericarditis, or increased } \\
\text { intracranial pressure }\end{array}$ \\
\hline Tachyphylaxis, ileus, constipation, urinary retention, pupillary dilation & Ganglionic blocker & Postoperative glaucoma \\
\hline $\begin{array}{l}\text { Chest pain, nausea, vomiting, dizziness, headache, nasal congestion, } \\
\text { arrhythmia }\end{array}$ & $\alpha$-adrenergic blocker & $\begin{array}{l}\text { Angina, coronary insufficiency, MI or history of } \mathrm{MI} \text {, } \\
\text { hypersensitivity to mannitol }\end{array}$ \\
\hline
\end{tabular}

Table 6: Major Side Effects of Parenteral Drugs Commonly Used in the Treatment of hypertensive emergencies [14].

antihypertensive medications such as diazoxide, esmolol, enalaprilat, fenoldopam, hydralazine, labetalol, nicardipine, nitroglycerin, nitroprusside, or trimethaphan and for a slower BP reduction which takes several hours to days, rapid-acting oral therapy is acceptable using captopril, clonidine, prazosin, labetalol, or minoxidil [14] (Tables 4-6).

\section{Nitroprusside, Diazoxide}

Nitroprusside is the drug of choice for acute hypertensive emergencies. Parenteral hydralazine is an intermediate treatment between oral agents and more aggressive therapies such as 
Citation: Woldu MA, Lenjisa JL, Tegegne GT, Yadeta DG, Chala DT (2014) The Current Practice of Hypertensive Crises Treatment and the Underestimated Role of Clinical Pharmacists in Ambo Hospital Medical Ward, Ethiopia. J Clin Case Rep 4: 445. doi:10.4172/21657920.1000445

Page 4 of 5

\begin{tabular}{|c|c|c|c|}
\hline Sr. No & Major DTPs & Specific DTPs & $\begin{array}{l}\text { Responsible agents for } \\
\text { Specific DTPs }\end{array}$ \\
\hline \multirow{3}{*}{ I } & \multirow{3}{*}{ Indication } & \multirow{2}{*}{$\begin{array}{l}\text { Unnecessary drug } \\
\text { therapy }\end{array}$} & Simvastatin \\
\hline & & & ASA \\
\hline & & $\begin{array}{c}\text { Needs additional drug } \\
\text { therapy }\end{array}$ & IV antihypertensive agents \\
\hline \multirow[t]{3}{*}{ II } & Effectiveness & Ineffective drug & HCT \\
\hline & & & nifedipine \\
\hline & & Dosage too low & $\begin{array}{l}\text { nifedipine } \\
\text { simvastatin }\end{array}$ \\
\hline \multirow[t]{2}{*}{ III } & Safety problems & Adverse drug reaction & nifedipine \\
\hline & & Dosage too high & None \\
\hline IV & $\begin{array}{l}\text { Compliance } \\
\text { problems }\end{array}$ & non compliance & $\begin{array}{l}\text { The patient was not adherent } \\
\text { to his medication and had } \\
\text { history of social drug use. }\end{array}$ \\
\hline
\end{tabular}

Table 7: Major DTPs identified in patient case I.S. Ambo hospital medical ward, Ambo, Ethiopia; 2014

nitroprusside or diazoxide [14,15]. However, treatment of hypertensive crises in patients with hypertensive encephalopathy, intracranial hemorrhage, subarachnoid hemorrhage, and thrombotic stroke has been recommended to be initiated with nicardipine, fenoldopam, nimodipine, flunarizine or labetalol. Whereas, the use of drugs such as nitroprusside, nitroglycerin, enalaprilat, or hydralazine should be avoided. Hence, such management will result in vasodilation effects without compromised Cerebral Blood Flow (CBF) induced by nitroprusside and nitroglycerin [14].

\section{Drug Therapy Problems (DTPs)}

Recent studies provided evidence that Simvastatin $40 \mathrm{mg} /$ day can reduce stroke risk in high-risk individuals (including patients with prior stroke) by $25 \%$, even in patients with LDL concentrations of less than $116 \mathrm{mg} / \mathrm{dL}[15,16]$. However, the use of simvastatin in I.S. was not rational because no lipid profile data was obtained and no CT scan was done (unavailable at the study place). However, the clinical pictures and patient history indicate high possibility of hemorrhagic stroke rather than ischemic stroke. So, an initial management approach of I.S. has to be targeting urgent reduction of BP. Beside these facts, the dose of Simvastatin ${ }^{\mathrm{a}}$ prescribed for I.S. was lower than the standard books [16].

Different stroke trials showed that, the use of ASAb resulted in a significant increase in hemorrhagic transformation of the infarction $[17,18]$. Hence, the use of ASA in I.S. was a safety concern (Table 7).

I.S: I.S has hypertensive crises with a BP of 190/110 mmHg. Plus, he was manifesting typical of stroke symptoms such as sudden onset of body weakness, difficulty of speech, inability to move his extremities, facial palsy; and difficulties in eating, moving and coughing. Therefore, I.S. should have been treated with intravenous antihypertensive agents such as nicardipine, fenoldopam, and nimodipine to reduce blood pressure by $25 \%$ within the first hour [4].

When nifedipine was given orally, as previously recommended, as a rapid-acting alternative to parenteral therapy in the acute management of hypertension; the dose should have to be titrated to $30-90 \mathrm{mg}$ in three divided doses. However, the use of nifedipine in such patients was not a reasonable option considering its life-threatening adverse events of ischemia, MI, and stroke [14,19].

\section{Role of Clinical Pharmacists}

Clinical pharmacists are an integral part of the health care system and seek to improve quality of pharmaceutical care by providing supportive services to health professionals and patients' alike. In a hypertension clinic, pharmacists can be a cost-effective alternative to physicians in management of patients, and they can improve clinical outcomes and patient satisfaction [20]. Studies also showed that Patients randomized to collaborative primary care-pharmacist hypertension management achieved significantly better blood pressure control compared to usual care [21]. In this specific case the clinical pharmacists tried their best to save the patient life until the last minutes.

\section{The major contribution made were:}

\section{$\checkmark$ ASA was discontinued}

$\checkmark$ Parentral antihypertensive agents such as nicardipine, fenoldopam, and nimodipine were recommended rather than the oral use nifedipine. The patient did not receive the recommended medications because of drugs unavailability and patient's unaffordability to buy the medications from private pharmacies.

\section{The Role of Endothelial Function and of Carotid Artery Abnormalities}

Endothelial dysfunction is a well-established response to cardiovascular risk factors and precedes the development of atherosclerosis [22] and its understanding has advanced greatly in the past decade [23]. However, the relationship between blood pressure and arterial stiffness is more difficult to ascertain because blood pressure is a major covariate in the various measurements of stiffness [23]. Endothelium-dependent vasodilation can be assessed in the coronary and peripheral circulations [22] and further it can be managed by pharmaceutical agents that decrease arterial stiffness include nitroglycerin, angiotensin-converting enzyme inhibitors and angiotensin receptor blockers, and calcium channel blockers [23,24].

In our case the association between endothelial dysfunction and hypertension cannot be confirmed because it requires further biomarker study and a single patient result can also not be used to extrapolate and discuss risk factor association.

\section{References}

1. Varon J, Marik PE (2003) Clinical review: the management of hypertensive crises. Crit Care 7: 374-384.

2. García GM, Miúdo V, Manuel Lopes Cda G, Vassuelela Gomes J (2014) Characterization of patients aged 45 or under admitted with hypertensive emergencies in the Hospital do Prenda. Rev Port Cardiol 33: 19-25.

3. Stafford EE, Wsill KK, Brooks-GumbertAN (2012) Management of Hypertensive Urgency and Emergency. Clinician Review 22: 20-25.

4. Price RS, Kasner SE (2014) Hypertension and hypertensive encephalopathy Handb Clin Neurol 119: 161-167.

5. (2004) Seventh Report of the Joint National Committee on Detection, Evaluation and Treatment of High Blood Pressure. National Institute of Health, USA.

6. Association $\mathrm{AH}$ (2011) "Understanding blood pressure readings".

7. Research. MFfMEa (2009) "Low blood pressure (hypotension) Causes".

8. Wijaya I, Siregar P (2013) Hypertensive crises in the adolescent: evaluation of suspected renovascular hypertension. Acta Med Indones 45: 49-54.

9. Milan A, Puglisi E, Ferrari G, Fabbri A, Rabbia F, et al. (2010) Hypertensive emergency and urgency: clinical update. G Ital Cardiol (Rome) 11: 835-848.

10. Gegenhuber A, Lenz K (2003) Hypertensive emergency and urgence. Herz 28: $717-724$

11. Nguyen TT, Rohrback SM, Lenamond C (2005) Distinguishing and Managing Hypertensive Emergencies and Urgencies. Improving Emergency Medicine Patient Care: EB Medicine.

12. Kaplan NM (2014) Drug treatment of hypertensive emergencies. 
Citation: Woldu MA, Lenjisa JL, Tegegne GT, Yadeta DG, Chala DT (2014) The Current Practice of Hypertensive Crises Treatment and the Underestimated Role of Clinical Pharmacists in Ambo Hospital Medical Ward, Ethiopia. J Clin Case Rep 4: 445. doi:10.4172/21657920.1000445

13. GAC (2008) Hypertension: Emergencies and Urgencies.

14. Summers K, Watson K, Michocki R (2009) Hypertensive Crises. Applied Therapeutics: The Clinical Use Of Drugs. (9thedn), Lippincott Williams \& Wilkins.

15. Chobanian AV, Bakris GL, Black HR (2003) Seventh report of the Joint National Committee on Prevention, Detection, Evaluation, and Treatment of High Blood Pressure.

16. Susan C Fagan, Hess DC (2005) Stroke. Pharmacotherapy: A Pathophysiologic Approach. (6th edn), NY: Mcgraw-Hill Medical Publishing Division.

17. (1997) CAST: randomised placebo-controlled trial of early aspirin use in 20,000 patients with acute ischaemic stroke. CAST (Chinese Acute Stroke Trial) Collaborative Group. Lancet 349: 1641-1649.

18. (1995) Tissue plasminogen activator for acute ischemic stroke. The National Institute of Neurological Disorders and Stroke rt-PA Stroke Study Group. N Engl J Med 333: 1581-1587.
19. (1988) Nifedipine, hypotension, and myocardial injury. Ann Intern Med 108 305-306.

20. Okamoto MP, Nakahiro RK (2001) Pharmacoeconomic evaluation of a pharmacist-managed hypertension clinic. Pharmacotherapy 21: 1337-1344.

21. Hunt JS, Siemienczuk J, Pape G, Rozenfeld Y, MacKay J, et al. (2008) A randomized controlled trial of team-based care: impact of physician-pharmacist collaboration on uncontrolled hypertension. J Gen Intern Med 23: 1966-1972.

22. Hadi HA, Carr CS, Al Suwaidi J (2005) Endothelial dysfunction: cardiovascular risk factors, therapy, and outcome. Vasc Health Risk Manag 1: 183-198.

23. Anderson TJ (2006) Arterial stiffness or endothelial dysfunction as a surrogate marker of vascular risk. Can J Cardiol 22 Suppl B: 72B-80B.

24. Mahmud A, Feely J (2002) Reduction in arterial stiffness with angiotensin II antagonist is comparable with and additive to ACE inhibition. Am J Hypertens 15: $321-325$ 